\title{
Sürdürülebilir Üretim için Grafit Takviyeli Polipropilen Kompozit Ürünlerin Bazı Termal ve Mekanik Özelliklerinin Deneysel Analizi
}

\author{
Ömer Şengül ${ }^{1 *}$, Musa Şeremet ${ }^{2}$, Menderes Kam $^{3}$ \\ Geliş / Received: 10/02/2020 \\ Revize / Revised: 13/04/2020 \\ Kabul / Accepted: 19/04/2020
}

\section{ÖZ}

Günümüzde, çevreye duyarlı üretim yöntemleri çerçevesinde ve doğal kaynakların ve enerjinin verimli kullanması, iklim değişikliğine sebep olan salınımların azaltmak için yeni ürünlere ihtiyaç duyulmuştur. Plastik malzemeler günlük hayatımızda önemli yer tutmaktadır. Termoplastik polimer malzemelerden olan polipropilen (PP), otomotiv sanayisi, tekstil ve yiyecek paketlemesi gibi çok geniş kullanım alanlarına sahiptir fakat bazı durumlarda istenilen özellikleri verememektedir. Bu malzemelerin özelliklerini daha iyileştirmek için kompozit malzemeye ihtiyaç duyulmaktadır. Sürekli gelişim ve değişim içinde olan kompozit malzemeler; maliyetlerin düşürülmesi, ürünün verimliliğinin ve kalitesinin arttırılması gibi birçok avantajlara sahiptir. Plastik malzemelere katkı olarak kullanılan bazı malzemeler plastik kompozit olarak mekanik ve termal özelliklerinde de iyileşmeler meydana getirmektedir. Bu çalışmada, \% 1 grafit maddesi ile yaygın olarak kullanılan polipropilen (PP) malzeme ile çift vidalı ekstrüder tezgahında homojen karışımı yapılarak, enjeksiyon makinesinde 100 adet standart test çubuğu üretimi yapılmıştır. Katkısız polipropilen (PP) ile prototipi yapılan ürün ve kompozit ürünün izod darbe testi, eriyik akış endeksi (MFI), 1sı deformasyon testi (HDT), sertlik testi (Shore-D), çekme testi ve yoğunluk testleri yapılmıştır. Test sonuçlarına göre, katkısız polipropilen (PP) ve Grafit katkılı polipropilen (GPP) kompozit malzemenin bazı termal ve mekanik özelliklerindeki değişmeler incelenmiştir. Sonuç olarak, bu iki malzemenin mekanik özellikleri yaklaşık olarak \% 30 üzerinde ve termal özelliklerinde de yaklaşık \% 15 üzerinde iyileşme meydana gelmiştir. Mekanik ve termal özelliklerinin iyileştirilmesi ile plastik sektöründe büyük avantajlar sağlayacaktır. Ayrıca, savunma sanayisi, havacılık ve otomotiv sektöründe yeni ürün olarak kullanılabileceği öngörülmüştür.

Anahtar Kelimeler-Sürdürülebilir Üretim, Polipropilen, Grafit, Mekanik Testler, Termal Testler

\footnotetext{
1*Sorumlu yazar iletişim: omersengullll@hotmail.com (https://orcid.org/0000-0001-5078-2002) Makine Mühendisliği, Fen Bilimleri Enstitüsü, Düzce Üniversitesi

2İletişim: musaseremet@hotmail.com (https://orcid.org/0000-0000-0000-0000)

Hatice Bayraktar Mesleki ve Teknik Anadolu Lisesi

3̇̉letişim: mendereskam@duzce.edu.tr (https://orcid.org/0000-0002-9813-559X)

Makine Metal Teknolojisi, Düzce Üniversitesi Dr. Engin PAK Cumayeri Meslek Yüksek Okulu
} 


\title{
Experimental Analysis of Some Thermal and Mechanical Properties of Graphite Reinforced Polypropylene Composite Products for Sustainable Production
}

\begin{abstract}
In this day and age, new products are needed within the structure of environmentally sensitive production methods and for efficient use of Natural Resources and energy to reduce the emissions that cause climate change. Plastic materials take an important place in our daily lives. Polypropylene (PP), which is a thermoplastic polymer material, has a wide range of uses in the automotive industry, manufactory and food packaging, but in some cases it does not provide the desired properties. Composite material is needed to further improve the properties of these materials. Composite materials that are constantly evolving and changing have many advantages such as reducing costs, increasing the efficiency and quality of the product. Some materials used as additives to plastic materials also produce improvements in their mechanical and thermal properties as plastic composites. In this study, 100 standard test bars were produced in the injection machine by making homogenous mixture of \% 1 graphite material with commonly used polypropylene (PP) material in double screw extruder machine. Pure polypropylene (PP) izod impact test with the prototype of the product and composite product, Melt Flow Index (MFI), Heat Deformation Test (HDT), hardness test (Shore-D) tensile test and density tests were conducted. According to the test results, some changes in thermal and mechanical properties of pure polypropylene (PP) and Graphite reinforced polypropylene (GPP) composite material were investigated. As a result, the mechanical properties of these two materials have improved by approximately $\% 30$ and thermal properties by approximately \% 15 . By improving its mechanical and thermal properties it will provide great advantages in the plastics industry. It is also envisaged that it could be used as a new product in the military industry, aviation and automotive sectors.
\end{abstract}

Keywords- Sustainable Production, Polypropylene, Graphite, Mechanical tests, Thermal tests 


\section{GİRIŞ}

Hayvan, bitki ve ağaçlardan elde edilen pamuk, kauçuk, ipek vb. doğal polimerler yüzlerce yıldır kullanılmaktadır. Protein, enzim, selüloz gibi diğer doğal polimerler de canlıların biyolojik ve fizyolojik süreçleri için büyük önem arz etmektedir. Günümüzde artan talebin ve endüstrideki gelişmelere paralel olarak yapay polimerlerin üretimleri yapılmaktadır [1]. Fakat bu polimer malzemelerin mekanik ve termal özelliklerinin gelişen endüstriye ayak uyduramaması ve yapısal özelliklerinin yetersiz kalmasından dolayı kompozit malzemelerin üretilmelerine ihtiyaç duyulmaktadır.

Endüstride çoğunlukla maliyeti düşük olan ve özelliklede geri dönüşümü rahatlıkla yapılabilen termoplastik polimer malzemeler kullanılmaktadır. Termoplastik polimer malzemelerden de polipropilen (PP) malzemesi 1sıl çarpılma direnci, yorulma dayanımı ve kimyasal olarak kararlı yapıda olmasından dolayı daha çok otomotiv endüstrisi, beyaz eşya ve elektrik-elektronik ürünlerinin aksanlarında yaygın olarak kullanılmaktadır $[1-3]$.

Termoplastik polimer malzemelerden olan polipropilen, bazı durumlarda mekanik ve termal özellikleri istenilen durumu karşılayamamaktadır. Bu yüzden de kompozit malzemelerin oluşturulmasına ihtiyaç duyulmaktadır. Kompozit malzemeler iki veya daha fazla malzemenin birleşerek yeni ürün oluşturulmasıdır ve böylece malzemenin mekanik ve termal özelliklerini iyileştirerek ürün taleplerini karşılamaktadır. Bu bağlamda, grafit; yumuşak, yüzeyi yağsı ve ince levhalar şeklinde, eğilme ve bükülme özelliğine sahip, bir karbon mineralidir. Nano boyutlu grafit tabakalarının çeşitli polimerlerde dolgu maddesi olarak kullanılmasıyla üstün nitelikli polimer kompozitler hazırlanabilmektedir [4]. Grafit, iki boyutta birbirine kuvvetli kovalent bağlarla bağlanan karbon atomlarının oluşturduğu ve frafen olarak isimlendirilen tabakaların zayıf van der waals bağlarıyla üst üste dizilmesiyle elde edilen bir malzemedir [5].

Enjeksiyon kalıplama, termoplastik malzemeler için en uygun üretim yöntemidir. Enjeksiyonla kalıplama sisteminde polimer malzemeler, ergitme işlemi, kalıp boşluğuna doldurma işlemi, soğutma ve parçaların kalıptan çıkarılması işlemlerinden geçilerek elde edilir [3]. Besleme hunisine konulan granül polimer ve kompozit malzeme vidanın emme hareketiyle enjeksiyon makinesinde beslenir. Uygulanan ssıtma ve vidanın hareketi ile oluşan sürtünme ısısıyla malzeme basınçla birlikte ergitilip silindir çıkışına doğru malzeme iletimi gerçekleştirilir. Ergimiş malzeme, vidanın ileri doğru hızlı olarak itilmesi ile çıkıştaki kalıbın içine sıvı halde enjekte edilir [1-3].

Şekil 1'de grafit malzemesinin kimyasal yapısı görülmektedir.

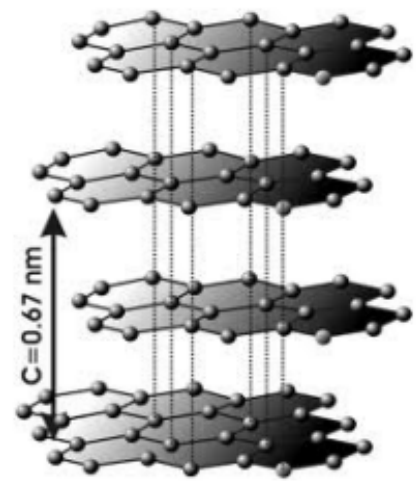

Şekil 1. Grafit malzemesinin kimyasal yapısı [6]

Literatürde polimer malzemelerden ürünler Ergiyik Depolayarak Modelleme (FDM - Fused Deposition Modeling) yöntemi ile de üretilmektedir. Daha karmaşık tasarımı yapılmış ürünlerin enjeksiyon kalıplarının 
yapılması oldukça maliyetli ve zor olduğundan dolayı karmaşık yapıdaki ürünlerin imalatı (FDM - Fused Deposition Modeling) yöntemi ile üretilmektedir. Bu kapsamda yapılmış literatürde polimer malzemelerin mekanik özelliklerinin incelenmesi ve analizi ile çok sayıda çalışma [8-12] yapılmıştır. Bu çalışmada ise, grafit takviyeli polipropilen kompozit malzemenin enjeksiyon yöntemi ile üretimi yapılarak, kompozit malzemenin bazı mekanik ve termal özellikleri deneysel olarak incelenmiştir. Bu sayede endüstride ihtiyaç duyulan ergonomik parçaların üretimi sağlanmış olacaktır.

\section{DENEYSEL ÇALIŞMALAR}

\section{A. Malzeme Üretimi}

Enjeksiyon kalıplama yöntemi, plastik malzemelere uygulanan üretim yöntemlerinin başında gelmektedir. Yapılan literatür çalışmalarında [5-6] grafit oranı \%1 olarak kullanılmıştır. Bu çalışmada ham polipropilen (PP) ve \% 1 oranında grafit partikülleri takviyeli polipropilen (GPP), çift vida etkili ekstrüderde homojen karışımı yapılarak enjeksiyon makinesinde 100 adet standart test çubuğu üretimi yapılmıştır. Şekil 2' de a) Enjeksiyon makinesi b) üretimi yapılan standart test çubuğu gösterilmiştir. Şekil 2'de enjeksiyon makinesinde, $45 \mathrm{~mm} / \mathrm{sn}$ enjeksiyon hızı ve 50 bar üretim basıncı ile tek vidalı kovan içerisinden dikdörtgen kesitli numuneler halinde üretilmiştir. Plastik çekme test çubuklarının ölçüleri (ASTM D638) standardında yapılmış ve plastik çekme test çubuğu imalatı enjeksiyon kalıplama yöntemi ile üretimi yapılmıştır.

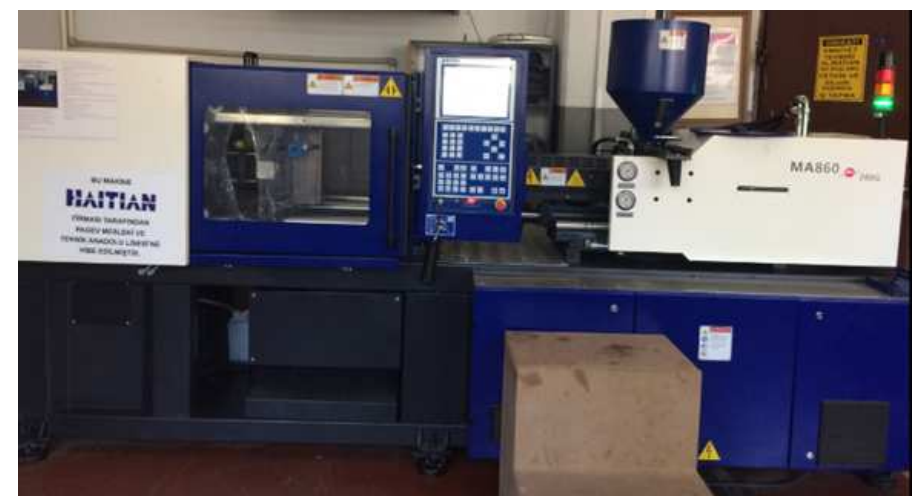

a)
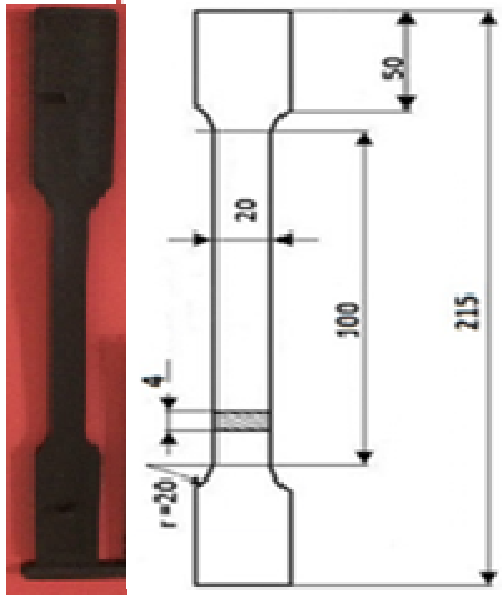

b)

Şekil 2. a) Plastik Enjeksiyon Makinesi b) Standart Test Çubuğu

\section{B. Testler ve Analizler}

Bir cisme uygulanan kuvvetler karşında göstermiş olduğu tepki, mekanik davranış olarak tanımlanır. Bu davranış biçimini mekanik özellikleri belirler. Malzemenin mekanik özellikleri, değişik tür zorlamalar altında oluşan gerilmeler şekil değiştirmeleri ölçerek ve gözleyerek de belirlenebilir. Cisimler, artan dış zorlamalar altında önce şekil değiştirir, sonra dayanımını yitirerek kırılır. Termal analiz yöntemi, malzemelerin fiziksel özelliklerinin sıcaklığa bağlı olarak değişiminin incelendiği deneysel bir yöntemdir. Termal analiz, malzemelerin kontrollü bir şekilde ısıtılarak ya da soğutularak, malzemelerin fiziksel özelliklerinde oluşan değişimin sıcaklığın bir fonksiyonu olarak ölçüldüğü yöntemleri içerir.

Polipropilen (PP) ve kompozit ürünün $250 \mathrm{kN}$ kapasite yük hücreleri ile Shimadzu marka üniversal test cihazı kullanılarak $1 \mathrm{~mm} /$ dak çekme hızında çekme testlerine tabi tutularak gerçekleştirilmiştir. Çekme testi her bir numune için üç kez tekrarlanmış ve sonuçların ortalaması alınmıştır. Tüm testler laboratuar ortamında yapılmıştır. 
Izod darbe testi, gevrek ve kırılmaya neden olabilecek şartlar altında çalışan malzemelerin mekanik özelliklerinin belirlenmesinde kullanılmaktadır. Özellikle, polimer malzemeler ve Hacim Merkezli Kübik yapılı metallerde çok büyük önem arz etmektedir. Izod darbe test cihazının özellikleri aşağıda belirtilmiştir.

Izod Darbe Test Cihazının Özellikleri;

- $\quad$ Sarkacin enerjisi 2,75 Joule,

- $\quad$ Aç1 150 derece,

- $\quad$ Genişlik $4 \mathrm{~mm}$,

- Kalınlık 8 mm, 2 mm çentik kalınlığı,

- $\quad$ Yerçekimi $9,84 \mathrm{~m} / \mathrm{s}^{2}$ şeklindedir.

Izod darbe test cihazı ve standart izod darbe test numuneleri $(80 \times 10 \times 4 \mathrm{~mm})$ ölçülerinde yapılmıştır. Testler her bir numune için üç kez tekrarlanarak ortalama değerleri alınmıştır.

Shore-D testi plastik ya da esnek olan malzemelerin sertliğini belirlemek için kullanılan geleneksel bir sertlik ölçme yöntemidir [14]. Polimerlerin, elastomerlerin ve kauçuk yapılı malzemelerin sertliğini belirlemek için kullanılmaktadır [14-15]. Enjeksiyon makinesi ile hazırlanan numunelerin sertlik testleri verilen ZWICK marka Shore D durometre cihazı ile yapılmıştır. Testler her bir numene için üç kez tekrarlanarak ortalama değerleri alınmıştır.

Eriyik Akış İndeksi testi (MFI) plastik malzemelerin ekstrüderde işlenmesi ve enjeksiyon makinesinde kalıplanarak şekil verilmesi sırasında gösterdiği akışkanlık davranışlarını belirlemek amacıyla yapılır [17]. Polimer malzemelerin kontrollü bir şekilde ssıtılarak ya da soğutularak, malzemelerin fiziksel davranışlarında meydana gelen değişimlerdeki değişimler için plastiklere termal testler uygulanır [13]. Polimer malzemelerde akışkanlık, ürünün işlenmesinde ve kalıplanmasında kritik öneme sahiptir. Bu nedenle de kontrolü önemli bir parametredir. Akışkan Indeksi MFI (ISO 1133) testi Melt Indeks test cihazı ile yapılmıştır. Cihaza ait bazı teknik bilgiler Tablo 1'de verilmiştir.

Tablo 1. Eriyik akış indeksi testi (MFI) test cihazı parametreleri

\begin{tabular}{ll}
\hline Sıcaklık $\left({ }^{\circ} \mathrm{C}\right)$ & 220 \\
Yer çekimi (g/cc) & 0,915 \\
Hacimsel erime akış hızı (MVR) & 1 \\
Kütlesel erime akış hızı (MFR) & 0 \\
Ön ısıtma yük süresi (sn) & 5 \\
Ölçüm zamanı (sn) & 10 \\
Yük (kg) & 2,75 \\
Meme çapı (mm) & 2,095 \\
Yük uzunluğu (mm) & 8 \\
10 sn de adımlardaki kesim ölçüsü $(\mathrm{mm})$ & 0,25 \\
\hline
\end{tabular}

Isı Deformasyon Testi (Heat Deflection Temperature - HDT); polimer, mamul ve yarı mamullerin yüksek sıcaklığa maruz kaldığında hangi sıcaklık değerine kadar sınırı olduğunun belirlenmesinde kullanılır [19]. HDT testleri ISO 75 standardına göre yapılmıştır. Numuneler (100x10x4mm) 3 farklı istasyonda test edilerek ortalama $0,118 \mathrm{~mm}$ derinlikte sekiz kez sıcaklıkları ölçülmüş ve sonuçların aritmetik ortalaması alınmıştır. Polipropilen (PP) polimer malzemesi için başlama sıcaklığ $127^{\circ} \mathrm{C}$, kompozit malzemesi için başlama sicaklığı $27^{\circ} \mathrm{C}$ olarak belirlenmiştir. 
Yoğunluk testi plastik malzemelerinin birim hacmindeki ağırlığının tespit edilmesinde ve yoğunluğunun tayin edilmesi amacı ile yapılır [20]. Testler RADWAG WAS 220/X model yoğunluk kiti olan hassas terazi ile ISO 1183 test standardına uygun olarak yapılmıştır.

\section{BULGULAR VE TARTIŞMA}

Bir malzemeyi seçip kullanmadan önce o malzemenin mekanik ve termal özelliklerini bilmek ve özelliklerini tespit etmek çok önemlidir. Yapılan bu çalışmada elde edilen kompozit malzemenin homojen karışımı ve prototipin üretimi enjeksiyon tezgahında yapılmıştır. PP ve GPP kompozit ürünlerin mekanik özelliklerini tespit etmek için izod darbe testi sonuçları Tablo 2 ve Tablo 3 'te gösterilmiştir.

Tablo 2. PP ürünün izod test sonuçları

\begin{tabular}{ccc}
\hline Test & Çekicin Harcanan Enerjisi (Joule) & İzod Sonucu $\left(\mathbf{k j} / \mathbf{m}^{\mathbf{2}}\right)$ \\
\hline $\mathbf{1}$ & 0,087 & 3,012 \\
$\mathbf{2}$ & 0,094 & 3,043 \\
$\mathbf{3}$ & 0,092 & 3,035 \\
\hline Ortalama & $\mathbf{0 , 0 9 1}$ & $\mathbf{3 , 0 3 0}$ \\
\hline
\end{tabular}

Tablo 3. GPP ürünün izod darbe test sonuçları

\begin{tabular}{ccc}
\hline Test & Çekicin Harcanan Enerjisi (Joule) & İzod Sonucu $\left(\mathbf{k j} / \mathbf{m}^{\mathbf{2}}\right)$ \\
\hline $\mathbf{1}$ & 0,119 & 4,132 \\
$\mathbf{2}$ & 0,106 & 3,681 \\
$\mathbf{3}$ & 0,115 & 4,102 \\
Ortalama & $\mathbf{0 , 1 1 3}$ & $\mathbf{3 , 9 7 1}$ \\
\hline
\end{tabular}

Izod darbe testi, gevrek ve kırılmaya neden olabilecek şartlar altında çalışan malzemelerin mekanik özelliklerinin belirlenmesinde kullanılır. Izod darbe testinin genel olarak amacı, malzemelerin dinamik zorlamalar altında kırılması için gerekli enerji miktarını, süneklik ve gevrek geçiş sıcaklı̆̆ını saptamaktadır.

Testler, üç adet polipropilen (PP) ve 3 adet kompozit ürün üzerinden yapılmıştır. Yapılan test sonuçlarının ortalaması alınmıştır ve yeni kompozit ürünün izod test sonucuna göre yaklaşı \% 31,5 mekanik özelliğinin arttı̆̆ tespit edilmiştir.

Çekme testi malzemede belirli şekil değiştirmeyi meydana getirmek için uygulanması gereken kuvvetin tespitinde veya ürüne belirli bir kuvvet uygulandığı zaman meydana gelecek şekil değişiminin belirlenmesini sağlar [21]. Bu mekanik test, mühendislikte büyük önem arz etmektedir [22]. Çekme testi sonuçları Tablo 4 ve Tablo 5'te verilmiştir.

Tablo 4. PP ürünün çekme test sonuçları

\begin{tabular}{clllll}
\hline Test & $\begin{array}{l}\text { Çekme } \\
\text { Mukavemeti } \\
\text { (MPa) }\end{array}$ & $\begin{array}{l}\text { Akma } \\
\text { Mukavemeti } \\
\text { (MPa) }\end{array}$ & $\begin{array}{l}\text { Elastikiyet } \\
\text { Modülü (MPa) }\end{array}$ & $\begin{array}{l}\text { Akmada } \\
\text { Uzama (mm) }\end{array}$ & $\begin{array}{l}\text { Kopmada } \\
\text { Uzama (mm) }\end{array}$ \\
\hline $\mathbf{1}$ & 29,963 & 26,139 & 1410,9 & 3,85 & 17,27 \\
$\mathbf{2}$ & 30,227 & 26,228 & 1965,8 & 3,33 & 14,84 \\
$\mathbf{3}$ & 30,504 & 25,887 & 1639,5 & 3,57 & 15,93 \\
\hline Ortalama & $\mathbf{3 0 , 2 3 1 3 3}$ & $\mathbf{2 6 , 0 8 4 6 7}$ & $\mathbf{1 6 7 2 , 0 6}$ & $\mathbf{3 , 5 8 3 3 3 3}$ & $\mathbf{1 6 , 0 1 3 3 3}$ \\
\hline
\end{tabular}


Tablo 5. GPP ürünün çekme test sonuçları

\begin{tabular}{clllll}
\hline Test & $\begin{array}{l}\text { Çekme } \\
\text { Mukavemeti } \\
(\mathbf{M P a})\end{array}$ & $\begin{array}{l}\text { Akma } \\
\text { Mukavemeti } \\
\text { (MPa) }\end{array}$ & $\begin{array}{l}\text { Elastikiyet } \\
\text { Modülü (MPa) }\end{array}$ & $\begin{array}{l}\text { Akmada } \\
\text { Uzama (mm) }\end{array}$ & $\begin{array}{l}\text { Kopmada } \\
\text { Uzama (mm) }\end{array}$ \\
\hline $\mathbf{1}$ & 28,447 & 25,816 & 1719,8 & 3,50 & 11,49 \\
$\mathbf{2}$ & 28,898 & 25,899 & 2080,6 & 3,24 & 8,71 \\
$\mathbf{3}$ & 29,079 & 25,808 & 1901,4 & 3,35 & 12,73 \\
Ortalama & $\mathbf{2 8 , 8 0 8}$ & $\mathbf{2 5 , 8 4 1}$ & $\mathbf{1 9 0 0 , 6}$ & $\mathbf{3 , 3 6}$ & $\mathbf{1 0 , 9 7}$ \\
\hline
\end{tabular}

Çekme testlerinde GPP kompozit ürünün elastikiyet modülünde artış meydana gelmiştir. Bu da yapılan ürünlerde şekil değişikliği biraz daha zor yapılabileceği belirlemiştir.

Lastik gibi yumuşak polimerlerde Shore-A, diğer polimerlerde ise Shore-D test yöntemi kullanılmaktadır [16]. Shore-D test sonuçları Tablo 6 ve Tablo 7'de gösterilmiştir.

Tablo 6. PP Shore-D test sonuçları

\begin{tabular}{cc}
\hline Test & Shore-D değeri \\
\hline $\mathbf{1}$ & 69 \\
$\mathbf{2}$ & 70 \\
$\mathbf{3}$ & 67 \\
\hline Ortalama & $\mathbf{6 8 , 6 6}$ \\
\hline
\end{tabular}

Tablo 7. GPP kompozit ürünün Shore-D test sonuçları

\begin{tabular}{cc}
\hline Test & Shore-D değeri \\
\hline $\mathbf{1}$ & 70 \\
$\mathbf{2}$ & 72 \\
$\mathbf{3}$ & 71 \\
\hline Ortalama & $\mathbf{7 1}$ \\
\hline
\end{tabular}

İmal edilen ürünlerin Shore-D testleri yapılmıştır ve GPP kompozit üründe yaklaşık \% 3 artış, yani sertliğinde iyileşme meydana gelmiştir.

Yoğunluk test sonuçları Tablo 8 ve Tablo 9'da gösterilmiştir. Test sonuçlarına göre PP ve GPP kompozit ürünlerin yoğunluklarında az bir değişiklik meydana gelmiştir.

Tablo 8. PP ürünün yoğunluk test sonuçları

\begin{tabular}{cc}
\hline Test & Yoğunluk gr/cm \\
\hline $\mathbf{1}$ & 0,89 \\
$\mathbf{2}$ & 0,90 \\
$\mathbf{3}$ & 0,89 \\
\hline Ortalama & $\mathbf{0 , 8 9 3}$ \\
\hline
\end{tabular}


Tablo 9. GPP kompozit ürünlerin yoğunluk test sonuçları

\begin{tabular}{cc}
\hline Test & Yoğunluk gr/cm ${ }^{3}$ \\
\hline $\mathbf{1}$ & 0,91 \\
$\mathbf{2}$ & 0,93 \\
$\mathbf{3}$ & 0,91 \\
\hline Ortalama & $\mathbf{0 , 9 1 6}$ \\
\hline
\end{tabular}
gelmiştir.

Yoğunluk test sonuçlarına göre yeni GPP kompozit ürünlerin yoğunluğunda \% 2,57 artış meydana

Termal testler ürünün kullanılacağı en düşük ve en yüksek sıcaklık aralığının belirlenmesi ve ürün hakkındaki ergime sıcaklığı, 1sı geçirgenliği, 1sıl genleşmesi, bozunma sıcaklığı gibi özelliklerin belirlenmesinde kullanılan test yöntemleridir [23]. Termal özelliklerden olan MFI (Eriyik Akış İndeksi) belirli sıcaklık ve yükleme koşulları altında belirlenmiş uzunlukta ve bilinen kesit alanına sahip nozuldan akan polimer malzemenin kütlesel veya hacimsel miktarını ölçmektedir [16]. Tablo 10 ve Tablo 11'de MFI sonuçları gösterilmiştir.

Tablo 10. PP ürünlerin (MFI) test sonuçları

\begin{tabular}{cc}
\hline Test & Eriyik Akıs Endeksi (MFI) Sonucu (g/10dak) \\
\hline $\mathbf{1}$ & 3,1 \\
$\mathbf{2}$ & 3,2 \\
$\mathbf{3}$ & 3,1 \\
\hline Ortalama & $\mathbf{3 , 1 3}$ \\
\hline
\end{tabular}

Tablo 11. GPP kompozit ürünün MFI test sonuçları

\begin{tabular}{cc}
\hline Test & Eriyik Akış Endeksi (MFI) Sonucu (g/10dak) \\
\hline $\mathbf{1}$ & 3,1 \\
$\mathbf{2}$ & 3,5 \\
$\mathbf{3}$ & 3,2 \\
\hline Ortalama & $\mathbf{3 , 2 6}$ \\
\hline
\end{tabular}

Testlerde üç adet ölçüm yapılmış ve bunların ortalaması alınmıştır. GPP kompozit ürünün viskozitesinde azalma olduğu görülmüştür. $\mathrm{Bu}$ da enjeksiyon yöntemi ile üretimi yapılan karmaşık yapılı ürünlerin üretiminde avantaj sağlamaktadır. GPP kompozit malzemenin termal özelliğinde yaklaşık \% 4,15 iyileşme olduğu belirlenmiş̧tir. HDT (Isı Deformasyon Testi); plastik, sert kauçuk, naylon yalıtım malzemeleri, takviyeli kompozit ve yüksek mukavemetli termoset ve termoplastik yumuşama noktasını ve sehimini belirleme sıcaklığını belirlemek için kullanılır [19]. Tablo 12 ve Tablo 13'te uygulanan HDT test sonuçları belirtilmiştir. 


\begin{tabular}{|c|c|c|}
\hline & $\begin{array}{l}\text { BŞEÜ Fen Bilimleri Dergisi } \\
7(1), 10-20,2020\end{array}$ & $\begin{array}{r}\text { BSEU Journal of Science } \\
\text { DOI: } 10.35193 / \text { bseufbd.687111 }\end{array}$ \\
\hline & & 58-7575 (http://dergipark.gov.tr/bseufbd) \\
\hline
\end{tabular}

Tablo 12. PP ürünün 1sı deformasyon test (HDT) sonuçlerı

\begin{tabular}{ccccccc}
\hline & \multicolumn{2}{c}{$\mathbf{1 .}$ İstasyon } & \multicolumn{2}{c}{ 2. İstasyon } & \multicolumn{2}{c}{ 3. İstasyon } \\
\hline Test & Derinlik $(\mathbf{m m})$ & Sicaklık $\left({ }^{\circ} \mathbf{C}\right)$ & Derinlik $(\mathbf{m m})$ & Sicaklık $\left({ }^{\circ} \mathbf{C}\right)$ & Derinlik $(\mathbf{m m})$ & Sicaklık $\left({ }^{\circ} \mathbf{C}\right)$ \\
\hline $\mathbf{1}$ & 0,01 & 26,2 & 0,01 & 26,9 & 0,01 & 27,1 \\
$\mathbf{2}$ & 0,04 & 28,3 & 0,04 & 28,5 & 0,04 & 29,6 \\
$\mathbf{3}$ & 0,07 & 30,0 & 0,07 & 31,2 & 0,07 & 32,3 \\
$\mathbf{4}$ & 0,10 & 32,1 & 0,10 & 33,4 & 0,10 & 33,1 \\
$\mathbf{5}$ & 0,13 & 33,0 & 0,13 & 34,9 & 0,13 & 34,8 \\
$\mathbf{6}$ & 0,17 & 35,2 & 0,17 & 35,7 & 0,17 & 35,9 \\
$\mathbf{7}$ & 0,20 & 36,3 & 0,20 & 37,6 & 0,20 & 37,8 \\
$\mathbf{8}$ & 0,23 & 37,8 & 0,23 & 38,5 & 0,23 & 38,8 \\
\hline$\Sigma \boldsymbol{O R T}$. & $\mathbf{0 , 1 1 8}$ & $\mathbf{3 2 , 3}$ & $\mathbf{0 , 1 1 8}$ & $\mathbf{3 3 , 3}$ & $\mathbf{0 , 1 1 8}$ & $\mathbf{3 3 , 6}$ \\
\hline
\end{tabular}

Tablo 13. GPP kompozit ürünün 1sı deformasyon test (HDT) sonuçlerı

\begin{tabular}{ccccccc}
\hline & \multicolumn{2}{c}{ 1. İstasyon } & \multicolumn{2}{c}{ 2. İstasyon } & \multicolumn{2}{c}{ 3. İstasyon } \\
\hline Test & Derinlik $(\mathbf{m m})$ & Sicaklık $\left({ }^{\circ} \mathbf{C}\right)$ & Derinlik $(\mathbf{m m})$ & Test & Derinlik (mm) & Sicaklık $\left({ }^{\circ} \mathbf{C}\right)$ \\
\hline $\mathbf{1}$ & 0,01 & 31,8 & 0,01 & 30,3 & 0,01 & 30,8 \\
$\mathbf{2}$ & 0,04 & 33,6 & 0,04 & 34,5 & 0,04 & 33,6 \\
$\mathbf{3}$ & 0,07 & 35,2 & 0,07 & 37,2 & 0,07 & 35,8 \\
$\mathbf{4}$ & 0,10 & 37,1 & 0,10 & 39,2 & 0,10 & 37,4 \\
$\mathbf{5}$ & 0,13 & 39,4 & 0,13 & 40,7 & 0,13 & 38,8 \\
$\mathbf{6}$ & 0,17 & 42,3 & 0,17 & 42,3 & 0,17 & 40,6 \\
$\mathbf{7}$ & 0,20 & 43,2 & 0,20 & 44,9 & 0,20 & 42,6 \\
$\mathbf{8}$ & 0,23 & 45,5 & 0,23 & 46,1 & 0,23 & 44,9 \\
$\Sigma \boldsymbol{O R T}$. & $\mathbf{0 , 1 1 8}$ & $\mathbf{3 8 , 5 1}$ & $\mathbf{0 , 1 1 8}$ & $\mathbf{3 9 , 4}$ & $\mathbf{0 , 1 1 8}$ & $\mathbf{3 8 , 0 6}$ \\
\hline
\end{tabular}

Çalışmada, üç istasyonda 8 adet ölçüm yapılmıştır ve bu ölçüm sonuçlarıın ortalaması hesaplanmıştır. GPP kompozit ürünlerin termal özelliklerinde yaklaşık \% 17 iyileşme olduğu görülmüştür. GPP kompozit ürünün sıcaklığa karşı eğilme direnci artmıştır.

\section{GENEL SONUÇLAR}

Yapılan bu çalışmada; \% 1 oranında polipropilen malzemesine grafit partikülleri eklenerek kompozit ürün oluşturulmuştur. Enjeksiyon makinesinde, prototip standart levha çekme test çubuklarının üretimi yapılmıştır. PP ile prototipi üretilen ürün ile grafit partikül takviyeli GPP kompozit ürünün izod darbe testi sonucunda, kompozit üründe yaklaşık \% 31,5 gibi bir iyileşme elde edilmiştir. Kompozit ürünün mekanik özelliği iyileşmiştir. Yapılan 1sı deformasyon (HDT) test sonuçlarına göre kompozit malzemenin termal özelliğinin oldukça iyileştiği, yaklaşık \% 38'lik eğilme sıcaklığının arttığı gözlenmiştir ve yaklaşık \% 17 termal özelliğinde iyileşme meydana gelmiştir. Eriyik Akış Endeksi (MFI) sonucuna göre yeni kompozit malzemenin viskozitesi azalmış ve malzemenin termal özellikleri yaklaşık \% 4,15 artmıştır. Sertlik testi (Shore-D) sonucunda kompozit ürünün sertliğinde ihmal edilecek değerlerde veriler elde edilmiştir. Yapılan çekme testi sonuçlarına göre GPP kompozit ürünün mekanik özelliklerinde önemli derecede iyileşmeler meydana gelmiştir. Sonuç olarak, GPP kompozit malzemenin savunma, havacilık ve otomotiv sanayinde alternatif yeni ürün olarak kullanılabileceği öngörülmektedir. 


\section{KAYNAKLAR}

[1] Şengül, Ö., \& Şeremet, M. (2019). Analysis of Thermal And Mechanical Properties of The Product Manufactured With Graphite Reinforced Polypropylene (PP) Composite Material. International Marmara Sciences Congress (Autumn) 28 Ekim-1 Kasım, Kocaeli.

[2] Onaran K. (2012). Malzeme Bilimi (12. Baskı), Bilim Teknik Yayınevi, İstanbul.

[3] Savaşçı, Ö. T., 2002. Ana hatları ile plastikler ve plastik teknolojisi, PAGYAY yayıncılık, İstanbul.

[4] Xu, J., Hu, Y., Song, L., Wang, O., Fan, W., \& Chen, Z. (2002). Preparation And Characterization Of Poly (Vinyl Alcohol) Graphite, 40, 445467.

[5] Şengül, Ö., Tugaytimur, C., \& Şeremet, M. (2019). Polietilen-Grafen Takviyeli Kompozitlerin Mekanik ve Termal Özelliklerinin Deneysel İncelenmesi. 3rd International Engineering Research Symposium (Iners'2019), 5-7 Eylül, Düzce.

[6] Cuhadaroğlu, A., \& Kara, E. (2018). Grafit: Bir Genel Değerlendirme. Teknik Bilimler Dergisi; 8 (1): 14 33. Retrieved from https://dergipark.org.tr/tr/pub/tbed/issue/34644/330629

[7] Kıyıc1, İ.A., Plazma püskürtme yöntemiyle üretilen hidroksiapatit-cam kompozit kaplamaların karakterizasyonu, Yüksek Lisans Tezi, Marmara Üniversitesi, İstanbul-Türkiye, (2011).

[8] Kam, M., Saruhan, H., \& İpekçi, A. (2018). Investigation the effects of 3D printer system vibrations on mechanical properties of the printed products. Sigma J. Eng and Nat. Sci; 36(3): 655-666.

[9] İpekçi, A., Kam, M., \& Saruhan, H. (2018). Investigation of 3D printing occupancy rates effect on mechanical properties and surface roughness of PET-G Material Products. Journal of New Results in Science; 7(2): 1-8.

[10] Kam, M., İpekçi, A., \& Saruhan, H. (2017). Investigation of 3D printing filling structures effect on mechanical properties and surface roughness of PET-G material products. Gaziosmanpaşa Bilimsel Araştırma Dergisi; 6(ISMSIT2017): 114-121.

[11] Kam, M., Saruhan, H., \& İpekçi, A. (2019). Investigation the effect of 3d printer system vibrations on surface roughness of the printed products. Düzce Üniversitesi Bilim ve Teknoloji Dergisi; 7(2): 147-157.

[12] Kam, M., Saruhan, H., \& İpekçi, A. (2019). Farklı doldurma şekillerinin üç boyutlu yazıcılarda üretilen ürünlerin mukavemetine etkisi. Düzce Üniversitesi Bilim ve Teknoloji Dergisi;7(3): 951-960.

[13] TS 1005, (1994), Plastikler-Izod Darbe Mukavemetinin Tayini, Türk Standartlar Enstitüsü, Ankara.

[14] http://www.yalova.edu.tr/Files/UserFiles/158/Mekanik_Lab-10.07.2017_ozgur.pdf

[15] Jordan, D.R., Mawn, L.A., Brownstein, S., Gilberg, S.M., Hill, V., Grahovac, S.Z., Adenis Ophthal , J.P., Plast. Reconstr. Surg.16(5) (2000) 347-355.

[16] Cömert, Z.Y., Cömert, I.A.,Bakkaloğlu, Toz metalurjisinde kullanılan biyomalzemeler, 11th International Materials Symposium, (2004) 161-165.

[17] Durman, M. (1992), Kompozit Malzemeler Ders Notları, İ.T.Ü. Sakarya Üniversitesi Metalurji Mühendisliği Bölümü, Sakarya.

[18] Gamstedt, E.K., Nygard, P., \& Lindström, M., (2007). Transfer Of Knowledge From Papermaking To Manufacture Of Composite Materials. Proceedings of The 3rd Wood Fibre Polymer Composites İnternational Symposium, p.12, Bordeaux. 
[19] http://hubtuam.hitit.edu.tr/isi-altinda-deformasyon-ve-yumusama-noktasi-sicakliklari-belirleme-cihazi-hdtvicat.

[20] Olcay, Y., Akyol, M.,Gemci R., Polimer esaslı lif takviyeli kompozit malzemelerin arabirim mukavemeti üzerine farklı kür metodlarının incelenmesi: Uludağ Üniversitesi MühendislikMimarlık Fakültesi Dergisi, 7(1) (2002) 93

[21] Kayalı, E.S., Ensari, C., \& Dikeç, F. (19966. Metalik Malzemelerin Mekanik Deneyleri, İTÜ KimyaMetalurji Fakültesi Yayını, İstanbul.

[22] Yılmaz, S. (1999). Plastik Malzemelerin Mekanik özelliklerinin incelenmesi, Lisans Tezi, Dokuz Eylül Üniversitesi Mühendislik ve Mimarlık Fakültesi, Makine Mühendisliği, İzmir.

[23] Kartal, İ., \& Boztoprak, Y. (2019). Bor Nitrür Partikülleriyle Takviye Edilmiş Vinilester Matrisli Kompozitlerin Mekanik Özelliklerinin İncelenmesi, El Cezeri Fen ve Mühendislik Dergisi, vol. 6, no. 1, pp. 43-50, Dec.

[24] Yüksel, M., \& Meran, C. (2010). Malzeme Bilgisine Giriş Cilt 2, MMO.

[25] Gamstedt, E.K., Nygard, P., \& Lindström, M. (2007). Transfer of knowledge from papermaking to manufacture of composite materials. Proceedings of the 3rd wood fibre polymer composites international symposium, p.12, Bordeaux. 